\title{
Sekolah Ramah HAM Sebagai Upaya Penanggulangan Tindakan Kekerasan di Kalangan Siswa
}

\author{
Yordan Gunawan \\ Program Studi Hukum, Fakultas Hukum, Universitas Muhammadiyah Yogyakarta \\ Jalan Brawijaya, Tamantirto, Kasihan, Bantul, Yogyakarta, Indonesia \\ Email: yordangunawan@umy.ac.id \\ DOI: $10.18196 /$ ppm.37.264
}

\section{Mohammad Bima Aoron Hafiz}

Fakultas Hukum, Universitas Muhammadiyah Yogyakarta Jalan Brawijaya, Tamantirto, Kasihan, Bantul, Yogyakarta, Indonesia bimaaoron@umy.ac.id

\begin{abstract}
Abstrak
Pada dasarnya setiap orang memiliki hak asasi manusia (HAM) yang melekat sejak dilahirkan dalam kehidupannya. HAM melekat pada manusia sebagai makhluk ciptaan Tuhan. Dari itulah HAM wajib dihormati, dijunjung tinggi, dan dilindungi negara, hukum, serta pemerintah, demi kehormatan dan perlindungan harkat dan martabat manusia. Diseminasi nilai-nilai HAM di usia sekolah merupakan salah satu bentuk penanaman nilai-nilai HAM sejak dini, terutama dengan maraknya kasus kekerasan antar siswa, bullying, sampai dengan kejahatan yang mengakibatkan korban jiwa di kalangan siswa sekolah. Upaya ini dilakukan karena anak yang akan menjadi generasi penerus bangsa di masa akan datang. Program Pengabdian masyarakat berupa inisiasi Sekolah Ramah HAM adalah salah satu cara yang diharapkan mampu mengurangi dan mencegah kekerasan di kalangan siswa terus meningkat. Lokasi Pengabdian ini adalah Madrasah Muallimin dan Madrasah Muallimat yang berlokasi di Kota Yogyakarta. Program ini tidak hanya melibatkan antara peserta didik dengan guru tapi juga seluruh warga sekolah dan masyarakat sekitar sekolah serta orang tua murid. Setelah terbentuknya Sekolah ramah HAM ini diharapkan siswa dapat memahami serta menjunjung tinggi HAM itu sendiri, serta berkurangnya tindak kekerasan, terutama bullying di kalangan siswa di Kota Yogyakarta.
\end{abstract}

Kata Kunci: Sekolah Ramah HAM, Diseminasi HAM, Tindak kekerasan

\section{Pendahuluan}

Pada dasarnya setiap orang memiliki hak asasi manusia (HAM) yang melekat sejak dilahirkan dalam kehidupannya. HAM melekat pada manusia sebagai makhluk ciptaan Tuhan. Oleh karena itu, untuk menghormati dan melindungi martabat manusia, hak asasi manusia harus dihormati, dipertahankan, dan dilindungi oleh negara, hukum, dan pemerintah. Kekerasan di sekolah merupakan salah satu bentuk kekerasan yang paling terlihat terhadap anak. Kekerasan di sekolah bisa bermacam-macam bentuknya, mulai dari kekerasan fisik hingga kekerasan psikis. Hal ini sering diekspresikan melalui tindakan bullying, intimidasi, dan represi. ${ }^{1}$ Kekerasan di sekolah menciptakan rasa tidak aman dan ketakutan yang merusak iklim sekolah secara umum dan melanggar hak siswa untuk belajar di lingkungan yang aman dan tidak mengancam. Sekolah tidak dapat menjalankan perannya sebagai tempat belajar dan bersosialisasi jika anak tidak berada dalam lingkungan yang bebas kekerasan.

Pada 2015, studi yang dilakukan Plan International dan International Center for Women's Studies (ICRW) menunjukkan $84 \%$ anak di Indonesia mengalami kekerasan di sekolah. Studi ini dilakukan di 5 negara di wilayah Asia, yaitu Vietnam, Kamboja, Nepal, Pakistan, dan Indonesia. Survei dilakukan dari Oktober 2013 hingga Maret 2014 dan melibatkan 9.000 siswa

\footnotetext{
${ }^{1}$ Howard Gardner, 2009, Five Minds for the Future, Massachusetts, Harvard Business Press Books, hlm. 200.
} 
berusia 12-17 tahun, dari kalangan guru, kepala sekolah, orang tua dan lembaga swadaya masyarakat. $^{2}$

Data Komisi Perlindungan Anak Indonesia tahun 2016 menunjukkan sebanyak 250 siswa menjadi korban kekerasan, dan 135 anak menjadi pelaku kekerasan di sekolah. Ada 120 siswa yang menjadi korban perkelahian, dan 135 siswa termasuk anak-anak yang ikut perkelahian sesama siswa. Hasil survei KPAI tahun 2013 menunjukkan bahwa dari 1.026 responden anak di 9 provinsi (SD/Madrasah Ibtidaiyah (MI), SMP/MTS (Madrasah Tsanawiyah) dan SMA/MA (Madrasah Aliyah), di 9 provinsi diantaranya, 87,6\% anak mengaku pernah mengalami kekerasan fisik, dan psikologi sekolah mulai dari diejek, dipukuli. ${ }^{3}$

Global School Based Student Health Survey (GSHS), menyebutkan bahwa di tahun 2007, sekitar 40\% siswa berusia 13-15 tahun di Indonesia mengalami penyerangan secara fisik setelah menjalani masa akhir pembelajaran di sekolah, yang rata-rata berlangsung selama kurang lebih 12 bulan. ${ }^{4}$ Merujuk dan dan fakta dari berbagai hasil survei dan juga penelitian tersebut di atas, tampak jelas bahwa pelanggaran hak asasi manusia di area sekolah sudah sangat mengkhawatirkan.

Setiap anak berhak untuk hidup bebas dari kekerasan fisik dan psikologis. The Convention on the Rights of the Child mengharuskan negara untuk mengambil semua tindakan yang tepat untuk melindungi anak dari kekerasan. ${ }^{5}$

Sekolah Ramah Hak Asasi Manusia bertujuan untuk memberdayakan kaum muda dan mendorong partisipasi aktif semua anggota komunitas sekolah dalam mengintegrasikan nilainilai dan prinsip-prinsip hak asasi manusia ke dalam semua bidang kehidupan sekolah. Pengabdian ini mendorong dan mendukung pengembangan budaya global hak asasi manusia dengan memberdayakan siswa dan guru di sekolah menengah di Indonesia maupun seluruh dunia untuk menciptakan komunitas sekolah yang ramah hak asasi manusia. Sekolah yang berpartisipasi bekerja untuk mengembangkan pendekatan sekolah menyeluruh untuk pendidikan hak asasi manusia, mengintegrasikan nilai-nilai dan prinsip-prinsip hak asasi manusia ke dalam bidang utama kehidupan sekolah termasuk tata kelola, hubungan, kurikulum dan kegiatan ekstra kurikuler, dan lingkungan sekolah. Sekolah Ramah Hak Asasi Manusia menjangkau di luar kelas dan keluar ke masyarakat untuk mengubah cara orang berpikir tentang dan secara aktif berpartisipasi untuk menangani masalah hak asasi manusia. Ini didasarkan pada keyakinan bahwa dengan meningkatkan pengetahuan dan mengubah sikap dan perilaku di seluruh komunitas, budaya global hak asasi manusia menjadi mungkin. ${ }^{6}$

The United Nations Declaration on Human Rights Education and Training mendorong negara-negara untuk mempromosikan dan memastikan pendidikan dan pelatihan hak asasi manusia dikembangkan dan dilaksanakan dengan semangat partisipasi, inklusi, dan tanggung jawab: "Setiap orang berhak untuk mengetahui, mencari dan menerima informasi tentang semua

\footnotetext{
2 Anonim, 2017, "Debat Final: 84\% Anak Indonesia Alami Kekerasan di Sekolah" diakses dari Website Databoks melalui tautan https://databoks.katadata.co.id/datapublish/2017/02/10/84-anak-indonesia-alami-kekerasan-disekolah, diakses pada 1 Maret 2020.

${ }^{3}$ Komisi Perlindungan Anak Indonesia, 2016, "Data Kasus Perlindungan Anak Berdasarkan Lokasi Pengaduan dan Pemantauan Media Se-Indonesia Tahun 2011-2016", diakses dari Website Komisi Perlindungan Anak Indonesia (KPAI) melalui tautan https://bankdata.kpai.go.id/tabulasi-data/data-kasus-se-indonesia/data-kasus-perlindungananak-berdasarkan-lokasi-pengaduan-dan-pemantauan-media-se-indonesia-tahun-2011-2016, diakses pada 1 Maret 2020.

4 Anonim, 2019, “Global School Based Student Health Survey (GSHS): Indonesia”, diakses melalui Website Centers for Disease Control and Prevention melalui tautan https://www.cdc.gov/gshs/countries/seasian/indonesia.htm, diakses pada 1 Maret 2020.

${ }^{5}$ The Convention on the Rights of the Child.

${ }^{6}$ Maya Bialik, et. al., 2015, Character Education for the 21st Century: What Should Students Learn?, Boston Massachucetts, Center for Curriculum Redesign, hlm. 22.
} 
hak asasi manusia dan kebebasan mendasar dan harus memiliki akses ke pendidikan dan pelatihan hak asasi manusia". ${ }^{7}$

Pendidikan hak asasi manusia adalah praktik partisipatif yang bertujuan untuk memberdayakan individu dan komunitas, membekali mereka dengan pengetahuan, sikap, nilai dan keterampilan yang mereka butuhkan untuk menikmati dan menjalankan hak mereka serta untuk menghormati dan menegakkan hak orang lain. ${ }^{8}$ Pendidikan hak asasi manusia meliputi pendidikan tentang hak asasi manusia adalah pengetahuan dan pemahaman tentang norma, prinsip, instrumen, dan nilai hak asasi manusia yang melandasinya. Pendidikan melalui hak asasi manusia adalah pembelajaran melalui metode inklusif, partisipatif dan demokratis yang menghormati hak-hak pendidik dan peserta didik. Pendidikan hak asasi manusia adalah proses belajar mengajar yang memungkinkan praktik hak asasi manusia dalam kehidupan sehari-hari dan memberdayakan orang untuk menikmati dan menjalankan haknya serta menghormati dan menjunjung tinggi hak orang lain.

Sekolah memiliki peran penting dalam kehidupan kita dan komunitas. ${ }^{9}$ Sebagai cerminan masyarakat luas, sekolah merupakan kunci untuk menyosialisasikan generasi muda, mempersiapkan peserta didik untuk menjadi anggota masyarakat yang aktif dan terlibat. Di abad ke-21 yang saling terhubung dan mengglobal, kaum muda dihadapkan pada dunia yang beragam dan berubah di sekitar mereka, dunia di mana kemiskinan, ketidaksetaraan, dan ketidakadilan lainnya masih menjadi bagian dari kehidupan jutaan orang.

Hak asasi manusia dapat memberi pemahaman kepada sekolah di seluruh dunia bahwa bagaimana pelajar mengerti tentang kesetaraan, nondiskriminasi, inklusi, rasa hormat, martabat, dan partisipasi yang sangat penting untuk mencapai masyarakat global yang lebih damai dan adil. ${ }^{10}$ Pendidikan hak asasi manusia merupakan sarana kritis untuk menanamkan pengetahuan, keterampilan, sikap dan nilai yang dapat menumbuhkan budaya hak asasi manusia. Sekolah Hak Asasi Manusia sebagai suasana di mana semua anggota komunitas tertentu memahami, menghargai dan melindungi hak asasi manusia, di mana nilai-nilai kesetaraan, martabat, rasa hormat, nondiskriminasi, inklusi, dan partisipasi menjadi landasan kebijakan dan menjadi dasar untuk proses pengambilan keputusan dalam komunitas. ${ }^{11}$

Sekolah Ramah Hak Asasi Manusia adalah sekolah yang menganut hak asasi manusia sebagai inti operasi dan prinsip penyelenggaraan. Ini adalah komunitas sekolah tempat hak asasi manusia dipelajari, diajarkan, dipraktikkan, dihormati, dilindungi, dan dipromosikan. Ini adalah tempat di mana semua dilibatkan dan didorong untuk mengambil bagian, tanpa memandang status atau peran, di mana keragaman budaya dirayakan. Singkatnya, Sekolah Ramah Hak Asasi Manusia memastikan bahwa nilai dan prinsip hak asasi manusia merupakan inti dari pengalaman belajar dan hadir di semua bidang utama kehidupan sekolah; ini adalah sekolah yang "bersahabat" dengan hak asasi manusia.

Sekolah Ramah Hak Asasi Manusia mempromosikan suasana kesetaraan, nondiskriminasi, inklusi, rasa hormat, martabat dan partisipasi di seluruh sekolah secara keseluruhan. Pendekatan partisipatif yang sepenuhnya demokratis terhadap tata kelola sekolah di mana semua anggota komunitas sekolah dilibatkan dalam pengambilan keputusan yang mempengaruhi mereka. Pemberdayaan siswa, guru dan staf untuk berpartisipasi secara

\footnotetext{
${ }^{7}$ The United Nations Declaration on Human Rights Education and Training.

${ }^{8}$ Ulrika Bergmark, 2008, "I Want People to Believe in Me, Listen When I Say Something and Remember Me: How Students Wish to be Treated", Pastoral Care in Education, Vol. 26, No. 4, London, Routledge, hlm. 270.

${ }^{9}$ Victor Dulewicz dan Malcolm Higgs, 2005, "Assessing Leadership Styles and Organisational Context", Journal of Managerial Psychology, Vol. 20, No. 2, Melbourne, Emerald Publishing Pty Limited, hlm. 123.

10 Darin Eich, 2008, "A Grounded Theory of High-Quality Leadership Programs Perspectives From Student Leadership Development Programs in Higher Education”, Journal of Leadership \& Organizational Studies, Vol. 15, No. 2, California, SAGE Publications, hlm. 180.

${ }_{11}$ Robert Hogan dan Joyce Hogan, 2003, "Assessing Leadership: A View from the Dark Side", International Journal of Selection and Assessment, Vol. 9, No. 1, New Jersey, Wiley, hlm. 45.
} 
bermakna dan setara dalam pembuatan dan implementasi kebijakan dan praktik sekolah. Rasa inklusi dan keterkaitan yang meningkat yang menumbuhkan tanggung jawab bersama dan solidaritas lokal dan global. Pemikiran kritis dan keterlibatan siswa dalam perdebatan tentang hak asasi manusia dan perubahan sosial. Pengalaman belajar yang kaya tentang hak asasi manusia di dalam dan di luar kelas.

Sekolah Ramah Hak Asasi Manusia menggunakan pendekatan sekolah menyeluruh atau holistik untuk mengintegrasikan hak asasi manusia ke dalam bidang utama kehidupan sekolah. Ini juga disebut pendekatan berbasis hak untuk pendidikan hak asasi manusia. Melalui pendekatan whole school, komunitas sekolah tidak hanya melihat apa yang diajarkan, tetapi juga bagaimana hal itu diajarkan, dengan tujuan untuk menciptakan budaya HAM di masyarakat.

Artikel ini bertujuan untuk menghapus kekerasan di sekolah dengan mendidik anak-anak tentang hak asasi manusia dan kewarganegaraan demokratis. Setelah terbentuknya Sekolah ramah HAM ini diharapkan siswa dapat memahami serta menjunjung tinggi HAM itu sendiri, serta berkurangnya tindak kekerasan, terutama bullying di kalangan siswa di Kota Yogyakarta. Pendidikan memainkan peran penting dalam pencegahan dan pemberantasan kekerasan di sekolah. The International Covenant on Civil and Political Rights menyediakan alat bagi negara-negara anggota untuk bertindak untuk memerangi semua bentuk diskriminasi dan kekerasan, terutama penindasan dan pelecehan.

\section{Metode Pelaksanaan}

\section{Tempat dan Waktu}

Lokasi pengabdian ini dilaksanakan di Madrasah Muallimin dan Madrasah Muallimat yang berlokasi di Kota Yogyakarta. Pelaksanaan Kegiatan Pada bulan Januari-Februari 2020.

\section{Khalayak Sasaran}

Khalayak sasaran dalam kegiatan adalah para pelajar (siswa-siswi) Madarasah Aliyah Muallimin dan Madrasah Muallimat Yogyakarta sebagai penerima manfaat. Kelompok sasaran ini sengaja dipilih dengan pertimbangan: (a) memiliki reputasi sebagai salah satu sekolah unggulan/favorit di Yogyakarta, para siswanya diasumsikan mempunyai kemampuan diatas rata-rata sehingga akan mudah memahami materi kegiatan, (b) merepresentasikan jumlah siswa/siswi di kalangan pelajar atau di sekolah-sekolah menengah atas (SMA/ Madrasah Aliyah) se-Daerah Isitimewa Yogykarta, (c) Pelajar SMA yang rentan pengaruh kekerasan antar siswa, bullying, sampai dengan kejahatan yang mengakibatkan korban jiwa di kalangan siswa sekolah, sehingga dianggap perlu menjadi percontohan siswa yang menjunjung tinggi HAM; (d) diasumsikan mempunyai animo partisipasi dalam Program Sekolah Ramah HAM, oleh karena itu perlu, pendidikan penanaman nilai-nilai HAM sejak dini yang mencerdaskan sesuai indikator/kategori yang telah dipetakan oleh Tim pelaksana kegiatan.

\section{Metode Pengabdian}

1. Tahap Awal Persiapan. Tim melakukan kordinasi dan komunikasi terlebih dahulu dengan pihak pimpinan Madrasah Muallimin dan Madrasah Muallimat Yogyakarta pada Minggu Pertama, Minggu Kedua, dan Minggu Ketiga, untuk memastikan terselenggaranya kegiatan pengabdian dimaksud sesuai target dan waktu yang telah ditentukan. Selanjutnya pada Minggu Keempat, Tim melakukan rangkaian rapat/meeting koordinasi teknis internal yang mencakup diantaranya: (a) melakukan rapat orientasi staf secara internal, (b) proses pendistribusian beban dan tanggungjawab kerja, (c) mempersamakan persepsi tentang dinamika kerja, (d) target yang ingin dicapai, (d) penentuan tugas antar staf, termasuk (e) rapat penyiapan teknis kelengkapan acara/kegiatan. 
2. Tahap Pelaksanaan. Pada Februari 2020 merupakan fase terakhir/final dari pelaksanaan kegiatan pengabdian. Kelompok sasaran penerima manfaat yang sudah teridentifikasi, diasumsikan mereka belum memiliki pengetahuan dan tingkat kesadaran yang memadai mengenai pentingnya pendidikan Sekolah Ramah HAM yang mencerdaskan bagi pelajar. Karenanya, materi dalam pelaksanaan kegiatan ini setidaknya mencakupnya: (a) arti penting/implikasi Hak Asasi Manusia bagi setiap manusia; (b) pentingnya memahami keberagaman sesama pelajar, dan (c) memberdayakan kaum muda dan mendorong partisipasi aktif semua anggota komunitas sekolah dalam mengintegrasikan nilai-nilai dan prinsip-prinsip hak asasi manusia ke dalam semua bidang kehidupan sekolah.

Pelaksanaan kegiatan dalam bentuk ceramah, pelatihan dan model participatory learning atau "role playing". 12 Model penyampaiannya dikemas/dirangkai dalam suasana diskusi interaktif yang bersifat nonformal sehingga memacu keingintahuan para pelajar lebih maksimal dalam menggali materi-materi kegiatan. Dengan pendekatan "role playing" (participatory learning), para partisipan dibuat lebih santai dan atraktif dengan penyajian beberapa simulasi dan contoh-contoh kasus aktual/kontekstual terkait pendidikan Sekolah Ramah HAM yang baik bagi pelajar, guru dan tenaga pendidik.

Adapun teknik pelaksanaannya, meliputi: (a) identifikasi calon peserta dengan target tingkat partisipasi sebesar $80 \%$ dari total jumlah siswa/siswi di Madarasah Aliyah Muallimin dan Madrasah Muallimat Yogyakarta, (b) mengundang peserta yang telah terindentifikasi, (c) menyiapkan ATK kegiatan dan tempat kegiatan, (d) menyiapkan konsumsi meeting/acara (e) mengundang nara sumber/fasilitator, (f) ceramah pengantar diskusi/kegiatan dari yang mewakili pimpinan Madarasah Aliyah Mualimin/Mualimat, yang dipandu pembawa acara, (g) Penyampaian materi oleh narasumber/fasilitator, dan (h) diskusi langsung dengan alur interaktif/participatory learning antara para peserta/partisipan dengan narasumber (i) simpulan dan rekomendasi.

Indikator Keberhasilan. Sejumlah indikator keberhasilan yang menjadi tolok ukur, sebagai berikut: (a) pengetahuan akan Hak Asasi Manusia makin meningkat (b) meningkatnya kesadaran akan pentingnya menghormati keberagaman, saling membantu jika melihat hak-hak asasi manusia teman dilanggar, dan kesadaran untuk menuntut hak-hak asasi manusianya yang terlanggar dan (c) mampu mengurangi dan mencegah kekerasan di kalangan siswa yang terus meningkat.

Monitoring dan Evaluasi. Hal-hal yang dimonitor dan dievaluasi (Monev) adalah keseluruhan progres pelaksanaan kegiatan dari tahap awal persiapan hingga akhir pelaksanaan. Hasil monitoring dan evaluasi akan dijadikan bahan evaluasi dan bahan laporan bulanan. Mekanisme monitoring dan evaluasi dilaksanakan secara partisipatoris. Setiap akhir kegiatan, partisipan dimintai pendapatnya mengenai dampak positif yang dirasakan oleh para partisipan termasuk memberikan masukan untuk kegiatan serupa dimasa mendatang dengan kelompok sasaran/partisipan lain dikalangan pelajar di lingkungan sekolah SMA/SMK/Aliyah di D.I. Yogyakarta. Hasil evaluasi partisipan akan dikomparasikan dengan hasil pengamatan staf terhadap pelaksanaan kegiatan sehingga bisa mendapatkan jawaban-jawaban secara objektif. Dengan demikian stakeholder yang terlibat sebisa mungkin dilibatkan dalam monitoring dan evaluasi kegiatan ini.

Keberlanjutan. Diharapkan sejumlah gagasan/ide/kontribusi pemikiran yang lahir dari para partisipan/narasumber, dapat melahirkan desain program lanjutan yang lebih luas jangkuannya

12 Kesi Widjajanti, 2011, "Model Pemberdayaan Masyarakat”, Jurnal Ekonomi Pembangunan, Vol. 12, No. 1, Solo, Muhammadiyah University Press, hlm. 18. 
serta tidak terbatas dikalangan pelajar. Melalui program ini, para partisipan/mitra akan termotivasi untuk berpatisipasi aktif dan tidak apatis untuk mengimplementasikan Sekolah Ramah HAM. Program ini bisa menjadi rule of mudel/pilot project dan bahkan para partisipan bisa menjadi kelompok katalisator, yang mendorong kelompok (calon partispan) lain dikalangan pelajar di Yogykarta untuk melibatkan diri atau melakukan kegiatan yang sama demi terwujudnya Sekolah Ramah HAM di Indonesia.

\section{Hasil dan Pembahasan}

\section{Ceramah}

Program Ceramah ini dibawakan oleh Tim Pengabdi sendiri, dan dibagi 2 sesi. Sesi 1 bertempat di Aula Asrama Madrasah Muallimin Muhammadiyah Yogyakarta dan materi dibawakan oleh bapak Yordan Gunawan S.H., M.H., Int.MBA yang juga merupakan Dosen Pengampu mata kuliah Hak Asasi Manusia di Fakultas Hukum Universitas Muhammadiyah Yogyakarta dan hadir para pelajar dari Madrasah Muallimin Muhammadiyah Yogyakarta. Dalam sesi 1 ceramah ini, para pelajar sangat antusias mengikuti program ini dan dibuktikan dengan banyak pertanyaan yang berkaitan tentang hak-hak asasi manusia.

Program Ceramah sesi ke 2 dilaksanakan di Aula Madrasah Muallimat Muhammadiyah Yogyakarta dan dihadiri oleh siswi Muallimat Muhammadiyah Yogyakarta, materi ceramah dibawakan oleh bapak Yordan Gunawan S.H., M.H., Int.MBA yang juga merupakan Dosen Pengampu mata kuliah Hak Asasi Manusia di Fakultas Hukum Universitas Muhammadiyah Yogyakarta. Dalam sesi 2 ceramah ini, para pelajar sangat antusias mengikuti program ini dan dibuktikan dengan banyak pertanyaan yang berkaitan tentang hak-hak asasi manusia.

Target dari program ceramah ini adalah bagaimana pelajar dari Madrasah Muallimin Muhammadiyah Yogyakarta dan Madrasah Muallimat Muhammadiyah Yogyakarta mengerti bagaimana cara mengimplementasikan Sekolah Ramah HAM dan bagaimana prinsip-prinsip hak asasi manusia, misalnya bagaimana generasi muda saling menghormati, menjunjung tinggi keberagaman. Program ceramah ini juga difungsikan sebagai ajang diskusi berkaitan dengan persoalan-persoalan seputar hak asasi manusia, sekaligus mencari solusi terhadap persoalan hak asasi manusia tersebut (peran siswa dan tenaga pendidik) demi terciptanya Sekolah Ramah HAM yang berkualitas yang menghasilkan calon Pemimpin masa depan yang menjunjung tinggi Hak Asasi Manusia, Amanah, Jujur, dan Berkualitas.

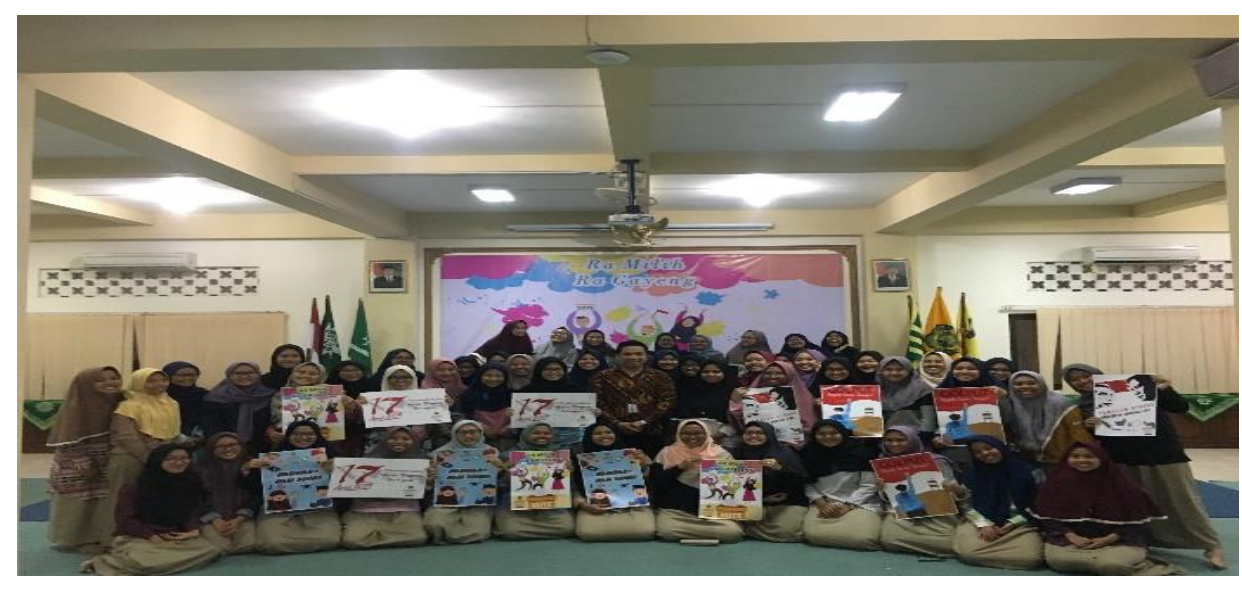

Gambar 1. Program Ceramah

Pada program ceramah ini pemateri menjelaskan juga 10 Prinsip Global untuk Sekolah Ramah Hak Asasi Manusia yang dikembangkan untuk mendukung komunitas sekolah di seluruh dunia untuk mengintegrasikan hak asasi manusia ke dalam kehidupan sekolah. Dasar dari 
proyek Sekolah Ramah Hak Asasi Manusia, prinsip-prinsipnya didasarkan pada standar, norma dan instrumen hak asasi manusia nasional maupun internasional, termasuk:
a. Deklarasi Universal Hak Asasi Manusia
b. Konvensi Hak Anak
c. Kovenan Internasional tentang Hak Ekonomi, Sosial dan Budaya
d. Kovenan Internasional tentang Hak Sipil dan Politik
e. Konvensi Penghapusan Segala Bentuk Diskriminasi terhadap Perempuan
f. Deklarasi PBB tentang Pendidikan dan Pelatihan Hak Asasi Manusia
g. Undang-Undang No. 39 Tahun 1999 tentang Hak Asasi Manusia

Instrumen nasional maupun internasional ini memiliki tujuan yang sama: untuk memajukan hak asasi manusia di seluruh dunia kepada semua orang. Mereka semua juga dengan jelas merinci pendidikan sebagai hak, serta metode kunci untuk mewujudkan hak-hak lain. 10 Prinsip Global menguraikan bagaimana sekolah dapat mengambil nilai dan hak yang diabadikan dalam instrumen ini dan menerapkannya di lingkungan sekolah. ${ }^{13}$

Prinsip 1: Sekolah Ramah Hak Asasi Manusia adalah komunitas di mana kesetaraan, nondiskriminasi, martabat, dan rasa hormat mendukung semua aspek kehidupan sekolah. Agar sekolah menjadi ramah HAM, sekolah harus mengakui dan mendukung nilai-nilai yang melandasi HAM, yang menjamin kesetaraan dan martabat setiap orang di lingkungan sekolah. Sekolah Ramah Hak Asasi Manusia yang mengedepankan kesetaraan, nondiskriminasi, martabat, dan rasa hormat, secara aktif menunjukkan nilai-nilai hak asasi manusia.

Prinsip 2: Sekolah Ramah Hak Asasi Manusia menyediakan lingkungan belajar di mana semua hak asasi manusia dihormati, dilindungi dan dipromosikan. Sekolah Ramah Hak Asasi Manusia akan menciptakan lingkungan belajar di mana hak asasi semua orang dihormati, di mana praktik belajar dan mengajar menumbuhkan rasa hormat di antara anggota masyarakat dan mempromosikan hak asasi manusia siswa, guru, staf dan pemimpin sekolah. Sekolah Ramah Hak Asasi Manusia akan berusaha untuk mempromosikan semua hak asasi manusia siswa, guru dan anggota komunitas sekolah lainnya, baik sipil atau politik, ekonomi, sosial atau budaya. Meskipun pada akhirnya menjadi tanggung jawab pemerintah untuk memastikan perwujudan hak asasi manusia, Sekolah Ramah Hak Asasi Manusia dapat memainkan peran penting dalam mendukung penyediaan hak asasi manusia, dan dengan demikian mendorong keselamatan, keamanan, dan rasa kebersamaan martabat dan keadilan menciptakan landasan untuk meningkatkan etos sekolah yang menghormati hak asasi manusia.

Prinsip 3: Sekolah Ramah Hak Asasi Manusia merangkul inklusi dalam semua aspek kehidupan sekolah. Sekolah dapat mempertemukan orang-orang dari berbagai latar belakang, budaya, agama, generasi, dan pengalaman. Dengan tidak adanya upaya yang kuat dan kewaspadaan dari semua anggota komunitas sekolah, akan mudah bagi perbedaan untuk disorot secara negatif atau perbedaan dari kelompok yang lebih rentan atau kurang sumber daya untuk distigmatisasi di dalam sekolah. Sekolah Ramah Hak Asasi Manusia berkomitmen pada kesetaraan, nondiskriminasi, rasa hormat dan martabat serta memberdayakan siswa dan anggota komunitas sekolah lainnya.

Prinsip 4: Sekolah Ramah Hak Asasi Manusia mendorong semua anggota komunitas sekolah untuk berpartisipasi secara bebas, aktif dan bermakna dalam kehidupan sekolah, termasuk membentuk kebijakan dan praktik sekolah. Partisipasi memiliki implikasi yang signifikan bagi pendidikan, dan Sekolah Ramah Hak Asasi Manusia menyadari bahwa anakanak khususnya harus dilibatkan dalam pengambilan keputusan tentang masalah yang mempengaruhi mereka. Partisipasi siswa dalam kehidupan sekolah telah dikaitkan dengan peningkatan hasil akademik. Peningkatan partisipasi orang tua dalam lingkungan akademis telah

\footnotetext{
${ }^{13}$ Peter Benenson, 2012, Becoming A Human Rights Friendly School: A Guidance for School Around the World, London, Amnesty International Ltd, hlm. 17.
} 
dibuktikan memiliki efek menguntungkan bagi sekolah dan komunitas. Sekolah Ramah Hak Asasi Manusia akan menawarkan kepada siswa dan anggota komunitas sekolah lainnya kesempatan untuk berpartisipasi dalam proses pengambilan keputusan. Dengan demikian, Sekolah Ramah Hak Asasi Manusia menciptakan kerangka kerja untuk memberdayakan siswa agar menjadi warga negara yang terinformasi dan aktif.

Prinsip 5: Sekolah Ramah Hak Asasi Manusia memastikan bahwa setiap orang di komunitas sekolah memiliki informasi dan sumber daya yang mereka butuhkan untuk berpartisipasi penuh dalam kehidupan sekolah. Memberikan kesempatan untuk partisipasi siswa, guru dan anggota komunitas sekolah lainnya mungkin tidak dengan sendirinya menjamin partisipasi aktif dan bermakna. Sekolah Ramah Hak Asasi Manusia perlu menyediakan semua informasi yang diperlukan untuk semua anggota komunitas sekolah sehingga mereka mengetahui bagaimana, di mana, dan kapan mereka dapat berpartisipasi secara bermakna dan efektif. Sekolah Ramah Hak Asasi Manusia akan memastikan bahwa informasi tentang kebijakan dan prosedur sekolah serta informasi relevan lainnya tersedia secara gratis untuk semua anggota komunitas sekolah. Sekolah Ramah Hak Asasi Manusia akan memfasilitasi partisipasi individu, dengan mempertimbangkan kebutuhan dan konteks khusus mereka.

Prinsip 6: Sekolah Ramah Hak Asasi Manusia adil, akuntabel, dan transparan dalam semua perencanaan, proses, kebijakan, dan praktiknya. Kepercayaan dibangun di sekolah dengan kebijakan yang transparan, adil dan inklusif serta budaya yang mengajak semua anggota komunitas sekolah untuk memahami dan berpartisipasi dalam pengambilan keputusan dan tindakan di sekolah. Sekolah yang memprioritaskan membangun budaya kepercayaan dan akuntabilitas dalam perencanaan, proses, kebijakan, dan praktiknya mendukung semua anggota komunitas sekolah untuk menjadi peserta aktif dalam kehidupannya sendiri. Sekolah Ramah Hak Asasi Manusia akan mengembangkan mekanisme untuk menyelesaikan perbedaan dan konflik yang menjunjung tinggi prinsip keadilan dan akuntabilitas, dan memastikan proses perencanaan dan pembuatan kebijakan transparan. Pimpinan sekolah, termasuk siswa dan anggota masyarakat, bertindak untuk meminta pertanggungjawaban satu sama lain, memastikan bahwa semua praktik sekolah sejalan dengan prinsip-prinsip hak asasi manusia sebagaimana tercermin dalam instrumen hak asasi manusia internasional.

Prinsip 7: Sekolah Ramah Hak Asasi Manusia melindungi semua anggota komunitas sekolah dengan menjadikan keselamatan dan keamanan sebagai tanggung jawab bersama. Semua pekerjaan yang dilakukan untuk memberikan pendidikan kepada siswa akan terancam jika siswa, guru, atau staf sekolah lainnya merasa terancam di lingkungan sekolah. Memastikan keselamatan dan keamanan semua anggota komunitas sekolah adalah tugas kolektif yang semua bertanggung jawab. Keselamatan dan keamanan kelompok marjinal atau rentan harus menjadi pertimbangan khusus oleh sekolah. Dengan memelihara lingkungan belajar yang aman, Sekolah Ramah Hak Asasi Manusia akan mendorong rasa solidaritas, martabat dan tanggung jawab bersama yang mendukung dan memfasilitasi pengajaran dan pembelajaran.

Prinsip 8: Sekolah Ramah Hak Asasi Manusia mengintegrasikan hak asasi manusia ke dalam semua aspek pengajaran dan kurikulum. Hak asasi manusia berasal dari seperangkat nilai dan prinsip yang disepakati secara internasional. Dengan demikian, mereka sering dilihat dalam abstraksi dan tanpa apresiasi penuh terhadap ruang lingkup dan penerapan potensialnya. Agar hak asasi manusia dipahami dan dipromosikan di seluruh komunitas sekolah, mereka harus diperkenalkan kepada siswa di ruang kelas dan kepada guru, administrator sekolah dan staf lain dalam pengaturan pengembangan profesional, tidak hanya melalui konten kurikulum atau kegiatan ekstra-kurikuler, tetapi juga melalui metodologi pengajaran. Hak asasi manusia harus hadir dalam bagaimana pengalaman belajar dibentuk, melalui pendekatan pedagogi yang menghormati hak asasi manusia dan mendorong partisipasi.

Prinsip 9: Sekolah Ramah Hak Asasi Manusia bekerja untuk memberdayakan semua siswa untuk mencapai potensi penuh mereka melalui pendidikan, khususnya siswa yang 
terpinggirkan karena jenis kelamin, status atau perbedaan mereka. Pendidikan hak asasi manusia berusaha untuk memberdayakan peserta didik untuk memahami dan menuntut hak-hak mereka dan menerima tanggung jawab mereka. Deklarasi Universal Hak Asasi Manusia menyatakan bahwa pendidikan harus "mengembangkan manusia seutuhnya" dan "meningkatkan penghormatan terhadap hak asasi manusia". Sekolah Ramah Hak Asasi Manusia akan menciptakan peluang bagi semua siswa, terutama mereka yang terpinggirkan karena jenis kelamin, status atau perbedaan mereka.

Prinsip 10: Sekolah Ramah Hak Asasi Manusia memberdayakan siswa dan staf untuk menjadi anggota aktif dari komunitas global, berbagi pengetahuan, pemahaman dan pembelajaran dengan orang lain dan mengambil tindakan untuk menciptakan dunia di mana hak asasi manusia dihormati, dilindungi dan dipromosikan. Kaum muda tumbuh sebagai anggota komunitas global yang semakin terhubung. Sekolah Ramah Hak Asasi Manusia akan mendukung kaum muda untuk menggunakan perspektif hak asasi manusia untuk memahami dunia ini, untuk terhubung dengan rekan-rekan mereka di seluruh dunia, untuk mengembangkan pemahaman tentang penghormatan terhadap budaya dan cara hidup yang berbeda, dan untuk mengembangkan pengetahuan dan keterampilan yang dibutuhkan untuk mengambil tindakan dalam menghadapi masalah global yang mendesak. Mendorong siswa untuk menjadi warga global yang aktif dan berpengetahuan akan membentuk bagian sentral dari sekolah yang ramah hak asasi manusia, memungkinkan siswa untuk menyadari bahwa mereka memiliki kekuatan dan tanggung jawab untuk mempengaruhi perubahan hak asasi manusia yang positif di dunia.

\section{Pelatihan}

Pelatihan pengabdian masyarakat dikembangkan dengan cara yang lebih sederhana yaitu melalui penyelenggaraan lokakarya dan diskusi informal, agar siswa tidak terlalu berat saat menerima materi pelatihan. Materi pelatihan yang diberikan mengambil beberapa kasus HAM sebagai contoh, sehingga peserta akan mendapatkan gambaran kasus dan strategi yang akan diterapkan. Selain itu, berbagi pengalaman juga dapat meningkatkan kreativitas dan kemampuan berinovasi siswa serta menentukan prasyarat untuk berhasilnya pendirian sekolah ramah HAM. Metode pelatihan melalui diskusi informal bertujuan untuk mendorong partisipasi dan perhatian peserta.

Pada kegiatan pelatihan ini, diisi oleh bapak Yordan Gunawan S.H., M.H., Int.MBA yang juga merupakan Dosen Pengampu mata kuliah Hak Asasi Manusia di Fakultas Hukum Universitas Muhammadiyah Yogyakarta dan Mohammad Bima Aoron Hafiz, S.H yang juga aktif dalam kegiatan penelitan dan pengabdian tentang Hak Asasi Manusia di Fakultas Hukum Universitas Muhammadiyah Yogyakarta. Program pelatihan ini dilaksanakan di aula Madrasah Muallimat Muhammadiyah Yogyakarta dan dihadiri ratusan pelajar dari Madrasah Muallimat Muhammadiyah Yogyakarta yang sangat antusias untuk menjadi pelajar yang paham akan nilainilai hak asasi manusia dan menjadi bagian dari Sekolah Ramah HAM.

Pada kegiatan pelatihan ini, para pelajar diajak menjadi agent of change dan mendorong partisipasi aktif semua anggota komunitas sekolah dalam mengintegrasikan nilai-nilai dan prinsip-prinsip hak asasi manusia ke dalam semua bidang kehidupan sekolah. Pelatihan ini juga membagikan poster yang bertuliskan jargon agar menjadi pelajar yang menerapkan nilai-nilai hak asasi manusia, dan menolak bullying, sampai dengan kejahatan yang mengakibatkan korban jiwa di kalangan siswa sekolah.

Beberapa elemen masyarakat yang mempunyai peran untuk hak asasi manusia di lingkungan sekolah, yaitu: ${ }^{14}$

\footnotetext{
${ }^{14}$ Melissa L Rocco dan Kimberly Griffin, 2015, "Exploring Leadership: For College Students Who Want to Make a Difference by Susan R. Komives, Nance Lucas, and Timothy R. McMahon (Review)", Journal of College Student Development, Vol. 56, No. 1, Maryland, Johns Hopkins University Press, hlm. 108.
} 


\section{Bagi Orang Tua dan Pengasuh Lainnya}

a. Sejak dini memperkenalkan lingkungan sekolah dan memastikan kesiapan anak untuk mulai sekolah.

b. Mendukung dan mengakui hak atas pendidikan dan nilai pendidikan bagi semua anak mereka.

c. Memastikan bahwa anak-anak tidak dibebani secara berlebihan dengan pekerjaan rumah tangga dan pekerjaan lain yang merugikan sekolah mereka. Orang tua perlu menciptakan ruang dan waktu dalam kehidupan anak agar mereka dapat bersekolah dan mengerjakan pekerjaan rumah.

d. Terlibat di sekolah dan mendukung pekerjaannya, melalui partisipasi dalam penggalangan dana, pertemuan dengan guru, komite, konsultasi, badan pengelola, dll.

e. Menunjukkan dorongan dan dukungan untuk pekerjaan anak mereka dan, jika memungkinkan, membantu pekerjaan rumah.

f. Mengadvokasi hak anak atas pendidikan, meminta pertanggungjawaban sekolah dan otoritas pendidikan dalam memenuhi kewajiban mereka kepada anak, memantau kemajuan, dan menantang pelanggaran hak.

g. Memastikan, sedapat mungkin, bahwa anak-anak mereka sehat dan bergizi sehingga mereka dapat belajar.

h. Memastikan bahwa tradisi dan adat istiadat setempat, seperti perkawinan anak, tidak menghalangi anak-anak mereka untuk bersekolah.

\section{Masyarakat}

Anak-anak tidak hanya hidup dalam keluarga tetapi juga dalam komunitas, yang nilai, budaya, dan tingkat keterlibatannya memiliki pengaruh yang signifikan pada kehidupan sehari-hari mereka. Masyarakat memiliki peran kunci dalam mendorong lingkungan yang kondusif untuk memenuhi hak atas pendidikan bagi setiap anak.

Anggota masyarakat lokal dapat menghasilkan advokasi penting untuk pendidikan dan meningkatkan sumber daya untuk meningkatkan fasilitas sekolah. Mereka dapat menyumbangkan dukungan keuangan, mengatur kegiatan penggalangan dana, bergabung dengan badan pengelola sekolah, mendukung kegiatan kurikulum berbasis masyarakat, berkontribusi pada 'pihak yang bekerja' untuk menjaga lingkungan sekolah, mengkampanyekan peningkatan pendanaan, membantu menyesuaikan gedung sekolah agar lebih mudah diakses untuk anak-anak penyandang disabilitas dan mendorong penghapusan pekerja anak di komunitas mereka. Keterlibatan aktif masyarakat lokal meningkatkan status sekolah dan mendukung persepsi bahwa pendidikan itu penting dan harus dihargai serta dilindungi untuk semua anak.

\section{Guru}

Sementara infrastruktur pendidikan yang lebih luas sangat penting, gurulah yang paling berdampak pada pengalaman sehari-hari anak-anak di sekolah. Pendidikan yang berkualitas dimana anak-anak ingin mengikuti pendidikan sangat bergantung pada komitmen, semangat, kreativitas, dan keterampilan guru. Tugas mereka adalah menerjemahkan kebijakan nasional menjadi tindakan praktis di setiap sekolah dan memastikan bahwa mereka merangkul budaya yang inklusif dan menghormati setiap anak. Agar hal ini bisa terwujud, sebagaimana dibahas sebelumnya, hak guru juga harus sepenuhnya diakui dan dihormati.

Kewajiban Guru dalam menegakkan hak asasi manusia di lingkungan sekolah:

a. Memperkenalkan langkah-langkah praktis untuk inklusi

b. Mempromosikan lingkungan yang saling menghormati 
c. Mengakomodasi kebutuhan yang berbeda

d. Mendorong keterlibatan local

e. Melibatkan anak-anak sebagai mitra

f. Menyeimbangkan hak dan tanggung jawab. ${ }^{15}$

\section{Organisasi Masyarakat Sipil}

Di kebanyakan negara di dunia, organisasi masyarakat sipil internasional, nasional dan lokal memainkan peran sentral dalam realisasi hak, baik sebagai penyedia layanan atau sebagai advokat yang menantang pengemban tugas untuk memenuhi kewajiban mereka. Mereka seringkali menjadi sumber keahlian yang cukup besar, tidak hanya di mana terdapat kesenjangan dalam penyediaan di masyarakat lokal tetapi juga tentang strategi yang diperlukan untuk mengatasi kesenjangan tersebut. Karenanya, membangun kemitraan dengan organisasi-organisasi ini menjadi sangat penting. Sektor swasta juga memainkan peran yang semakin penting dalam penyediaan layanan dasar, termasuk pendidikan, dan kebutuhan untuk memenuhi kewajibannya sebagai pengemban tugas. Oleh karena itu dapat menjadi mitra yang signifikan di banyak negara.

\section{Komunitas Internasional}

a. Memberikan keahlian teknis dan membangun kapasitas untuk membantu Negara memenuhi komitmen hak asasi manusia internasional mereka.

b. Memfasilitasi kapasitas pemangku kepentingan untuk menuntut hak-hak mereka, ini akan melibatkan pelatihan dan dukungan tentang hak asasi manusia untuk meningkatkan kapasitas mereka dalam mengadvokasi dan mengklaim hak-hak mereka, dan menciptakan peluang bagi mereka untuk melakukannya.

c. Meminta pertanggungjawaban Negara dengan komitmen terhadap hak asasi anak memiliki kewajiban untuk meminta pertanggungjawaban Negara atas komitmen yang telah mereka buat dalam meratifikasi perjanjian hak asasi manusia internasional.

d. Membangun kemitraan strategis untuk memperkuat lembaga efisiensi perlu berkolaborasi secara efektif untuk memastikan efisiensi dan efektivitas sebesar mungkin dalam kerja sama pemrograman dan pembangunan di tingkat global dan nasional.

e. Membangun perubahan sistemik, dalam jangka panjang, mereka yang paling tidak beruntung jelas paling baik dilayani oleh sistem pendidikan yang sepenuhnya inklusif dan non-diskriminatif.

f. Mendukung pengumpulan dan analisis data dari perspektif nasional, regional dan internasional untuk memfasilitasi pembuatan kebijakan yang terinformasi.

\section{Role Playing}

Dalam program ini, para pelajar memainkan peran sebagai elemen-elemen yang terlibat dalam Sekolah Ramah HAM melalui metode role playing yang menuntut keterlibatan peserta secara aktif dalam simulasi pelaksanaan Sekolah Ramah HAM. Tujuan metode ini adalah untuk menanamkan nilai-nilai HAM sejak dini, terutama dengan maraknya kasus kekerasan antar siswa, bullying, sampai dengan kejahatan yang mengakibatkan korban jiwa di kalangan siswa sekolah.

Sifat dan tingkat kekerasan di sekolah, yaitu:
a. Bullying;
b. Kekerasan seksual dan berbasis gender;
c. Kekerasan fisik dan psikologis;
d. Perkelahian, penyerangan fisik, dan kekerasan geng;

${ }^{15}$ Undang-Undang No. 20 Tahun 2003 tentang Sistem Pendidikan Nasional. 
e. Kekerasan terhadap anak-anak yang paling rentan

f. Tindakan perusakan fasilitas sekolah.

g. Pengabaikan terhadap kesetaraan hak anak perempuan. ${ }^{16}$

Pada kegiatan ini, para pelajar, guru dan staf yang ada di sekolah dilibatkan untuk mengikuti kegiatan ini dan dibagi menjadi beberapa kelompok dan diberi waktu untuk memperagakan konsep Sekolah Ramah HAM. Untuk siswa mempraktekkan bagaimana menghargai guru, staf, dan siswa lainnya dalam menjalani proses belajar mengajar di sekolah maupun kegiatan sehari-hari sehingga dapat terjalin dan tumbuh kembangnya kerja sama yang positif antara tenaga pendidik dan siswa dalam proses pembelajaran. Sedangkan para guru dan staf mempraktikkan pemahaman mereka tentang hak asasi manusia dan keterampilan dalam diskusi, inovasi, terkait dengan penerapan nilai-nilai hak asasi manusia. Menciptakan suasana yang kondusif di sekolah untuk meminimalkan perilaku kekerasan (seperti bullying dan perkelahian), sehingga tercipta sikap terbuka dan bertanggung jawab dalam tata kelola sekolah, sehingga membangun rasa percaya antara seluruh warga sekolah dan pihak terkait. Sekolah ramah hak asasi manusia ini diharapkan menjadi sekolah yang memandang nilai-nilai hak asasi manusia sebagai prinsip inti penyelenggaraan dan pengelolaan sekolah, di mana nilai-nilai atau prinsip-prinsip hak asasi manusia menjadi inti atau ruh dari proses dan pengalaman pembelajaran dan tercermin dalam seluruh aspek kehidupan di sekolah.

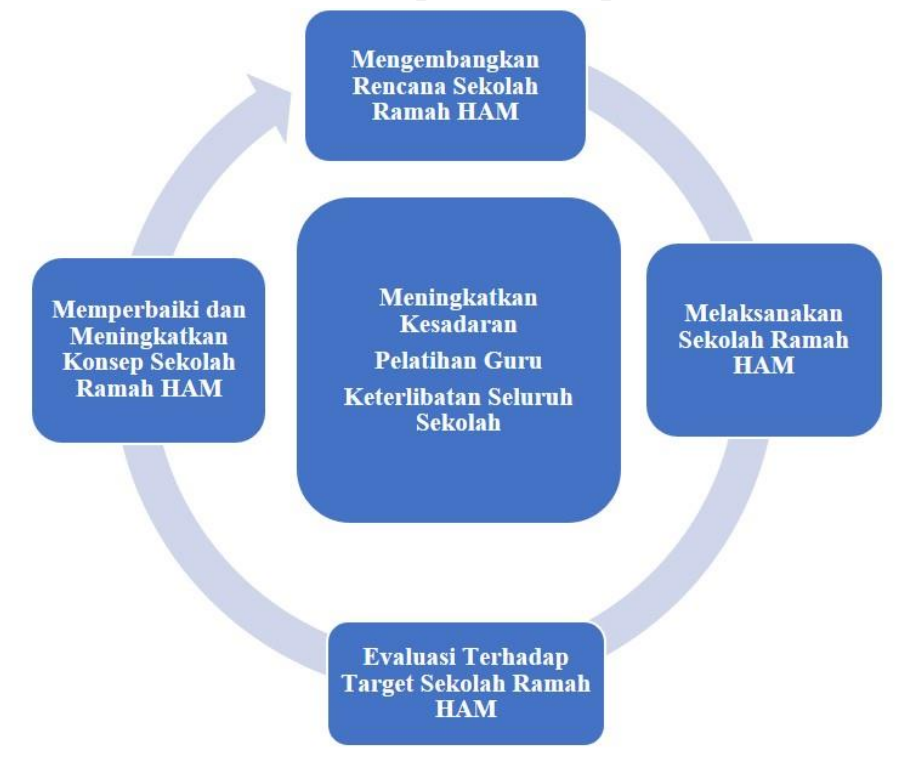

Diagram 1. Proses Monitoring Perkembangan Sekolah Ramah HAM

\section{Kesimpulan dan Saran}

Rangkaian kegiatan sejak tahap awal persiapan, monitoring dan evaluasi hingga proyeksi keberlanjutan diharapkan akan terjadi peningkatan kapasitas/pengetahuan hak asasi manusia yang baik oleh pelajar, tenaga pendidik, masyarakat, dan pemerintah. Dengan demikian, akan terbangun kesadaran untuk dapat menjaga nilai-nilai hak asasi manusia di dalam lingkungan sekolah maupun di lingkungan masyarakat. Melalui program ini, para pelajar, tenaga pendidik, masyarakat dan pemerintah akan termotivasi untuk berpartisipasi aktif dan tidak apatis untuk menjaga dan menjamin hak-hak asasi manusia di lingkungan sekolah maupun di lingkungan bermasyarakat. Program ini dapat menjadi role of model atau pilot project dimana para partisipan, diharapkan akan menjadi katalisator, mendorong kelompok (calon partispan) lainnya

\footnotetext{
16 Donald McCown, Diane K. Reibel, Marc S. Micozzi, 2010, Teaching Mindfulness: A Practical Guide for Clinicians and Educators, New York, Springer, hlm. 240.
} 
dan tidak terbatas dikalangan pelajar di Yogyakarta untuk melibatkan diri atau melakukan hal yang sama demi terwujudnya Sekolah Ramah HAM Indonesia di masa mendatang.

Pada dasarnya setiap orang memiliki hak asasi manusia (HAM) yang melekat sejak dilahirkan dalam kehidupannya. HAM melekat pada manusia sebagai makhluk ciptaan Tuhan. Maka dari itulah HAM wajib dihormati, dijunjung tinggi, dan dilindungi negara, hukum, serta pemerintah, demi kehormatan dan perlindungan harkat dan martabat manusia.

Berbagai bentuk pelanggaran HAM yang terjadi di sekolah telah menjadi perhatian negara, dan harus kita tanggapi dengan cepat, tepat dan tepat. Respon seperti itu diperlukan agar situasi serupa tidak terulang di kemudian hari. Berbagai cara dan upaya telah dilakukan oleh Kementerian/Lembaga untuk menghapus kasus pelanggaran HAM di sekolah. Namun, upaya tersebut gagal menunjukkan hasil terbaik. Masalahnya, upaya-upaya tersebut dilakukan berdasarkan sektor dan subjek, tidak bersatu, tidak partisipatif, dan tidak berkelanjutan. Sekolah Ramah Hak Asasi Manusia (SRH) merupakan cara baru untuk menyelesaikan berbagai pelanggaran hak asasi manusia di sekolah.

Sekolah ramah hak asasi manusia adalah sekolah yang menganggap nilai-nilai hak asasi manusia sebagai prinsip inti penyelenggaraan dan pengelolaan sekolah.Nilai atau prinsip hak asasi manusia merupakan inti atau ruh dari proses dan pengalaman pembelajaran, dan tercermin dalam segala aspek. Sendi kehidupan sekolah. Namun jika suatu konsep yang baik tidak dilaksanakan dengan benar maka akan menjadi sia-sia. Jika hal ini mendapat dukungan penuh dari Kementerian Pendidikan dan Kebudayaan dengan dukungan aktif Komnas HAM, kementerian / lembaga terkait, masyarakat, tokoh agama, tokoh masyarakat, lembaga internasional dan seluruh pemangku kepentingan terkait sekolah, maka program ini akan menjadi cara terbaik untuk menerapkan konsep sekolah ramah hak asasi manusia.

\section{Ucapan Terima Kasih}

Penulis dalam kegiatan ini menyampaikan apresiasi dan terima kasih kepada Pihak Universitas Muhammdiyah Yogyakarta, Kepala Sekolah Madrasah Aliyah Muallimin dan Madrasah Aliyah Muallimat Yogyakarta, para siswa/siswa partisipan, serta semua pihak lain terlibat dalam kegiatan ini.

\section{Daftar Pustaka}

\section{Buku dan Jurnal}

Benenson, Peter, 2012, Becoming A Human Rights Friendly School: A Guidance for School Around the World, London, Amnesty International Ltd.

Bergmark, Ulrika, 2008, "I Want People to Believe in Me, Listen When I Say Something and Remember Me: How Students Wish to be Treated", Pastoral Care in Education, Vol. 26, No. 4, London, Routledge.

Dara G Ghahremani, Eugene Y Oh, Andrew C Dean, Kristina Mouzakis, Kristen D Wilson, Edythe D London, 2013, "Effects of the Youth Empowerment Seminar on Impulsive Behaviour in Adolescents", Journal of Adolescent Health Brief, Vol. 53, No. 1, Amsterdam, Elsevier.

Donald McCown, Diane K. Reibel, Marc S. Micozzi, 2010, Teaching Mindfulness: A Practical Guide for Clinicians and Educators, New York, Springer.

Eich, Darin, 2008, “A Grounded Theory of High-Quality Leadership Programs Perspectives From Student Leadership Development Programs in Higher Education", Journal of Leadership \& Organizational Studies, Vol. 15, No. 2, California, SAGE Publications. 
Gardner, Howard, 2009, Five Minds for the Future, Massachusetts, Harvard Business Press Books.

Karen E. Hooker dan Iris E. Fodor, 2008, “Teaching Mindfulness to Children”, Gestalt Review Journal, Vol. 12, No. 1, Pennsylvania, Penn State University Press.

Kartika Sari, Joice, 2019, "Mindfulness Training to Reduce Exam Anxiety in Elementary Students", Psychological Journal, Vol. 5, No. 11, New Jersey, Wiley.

Kirk Warren Brown dan Richard M. Ryan, 2003, "The Benefits of Being Present: Mindfulness and Its Role in Psychological Well-Being", Journal of Personality and Social Psychology, Vol. 84, No. 4, Washington D.C., American Psychological Association.

Maya Bialik, Michael Bogan, Charles Fadel, Michaela Horvathova, 2015, Character Education for the 21st Century: What Should Students Learn?, Boston Massachusetts, Centers for Curriculum Redesign.

Melissa L Rocco dan Kimberly Griffin, 2015, “Exploring Leadership: For College Students Who Want to Make a Difference by Susan R. Komives, Nance Lucas, and Timothy R. McMahon (Review)", Journal of College Student Development, Vol. 56, No. 1, Maryland, Johns Hopkins University Press.

Orr, Debora, 2014, "The Uses of Mindfulness in Anti Oppressive Pedagogies: Philosophy and Praxis", Canadian Journal of Education, Vol. 27, No. 4, Canada, Canadian Society for the Study of Education.

Robert Hogan dan Joyce Hogan, 2003, "Assessing Leadership: A View from the Dark Side", International Journal of Selection and Assessment, Vol. 9, No. 1, New Jersey, Wiley.

Victor Dulewicz dan Malcolm Higgs, 2005, “Assessing Leadership Styles and Organisational Context", Journal of Managerial Psychology, Vol. 20, No. 2, Melbourne, Emerald Publishing Pty Limited.

Widjajanti, Kesi, 2011, "Model Pemberdayaan Masyarakat”, Jurnal Ekonomi Pembangunan, Vol. 12, No. 1, Solo, Muhammadiyah University Press.

Zinn, Jon Kabat, 2006, "Mindfulness Based Interventions in Context: Past, Present, and Future", Clinical Psychology Science and Practice Journal, Vol. 10, No. 2, New Jersey, Wiley.

\section{Peraturan Perundang-Undangan}

The Convention on the Elimination of All Forms of Discrimination Against Women

The Convention on the Rights of the Child

The International Covenant on Civil and Political Rights

The International Covenant on Economic, Social and Cultural Rights

The UN Declaration on Human Rights Education and Training

The Universal Declaration of Human Rights

Undang-Undang No. 20 Tahun 2003 tentang Sistem Pendidikan Nasional

Undang-Undang No. 39 Tahun 1999 tentang Hak Asasi Manusia

\section{Internet}

Anonim, 2017, "Debat Final: 84\% Anak Indonesia Alami Kekerasan di Sekolah" diakses dari Website Databoks melalui tautan https://databoks.katadata.co.id/datapublish/2017/02/10/84-anak-indonesia-alami-

kekerasan-di-sekolah, diakses pada 1 Maret 2020. 
Anonim, 2019, "Global School Based Student Health Survey (GSHS): Indonesia", diakses melalui Website Centers for Disease Control and Prevention melalui tautan https://www.cdc.gov/gshs/countries/seasian/indonesia.htm, diakses pada 1 Maret 2020.

Komisi Perlindungan Anak Indonesia, 2016, "Data Kasus Perlindungan Anak Berdasarkan Lokasi Pengaduan dan Pemantauan Media Se-Indonesia Tahun 2011-2016”, diakses dari Website Komisi Perlindungan Anak Indonesia (KPAI) melalui tautan https://bankdata.kpai.go.id/tabulasi-data/data-kasus-se-indonesia/data-kasusperlindungan-anak-berdasarkan-lokasi-pengaduan-dan-pemantauan-media-seindonesia-tahun-2011-2016, diakses pada 1 Maret 2020. 